\title{
Organizational Antecedents to and Consequences of Service Business Orientations in Manufacturing Companies
}

\begin{abstract}
Although various manufacturing companies have developed into total solution providers, no research addresses their service orientations. Building on the literature on organizational service climate, this study explores the organizational parameters and service business orientations that explain relative product sales and service volume of manufacturing companies. Following an exploratory study involving in-depth interviews, the authors conducted an empirical survey of 137 companies in the Netherlands, Belgium, and Denmark. The study assesses the effects of organizational parameters on the implementation of service business orientations and validates the important distinction between services in support of the client's actions (SSC) and services in the support of the product (SSP). The findings demonstrate that services in support of the client's action leverage relative product sales, while services in support of the product generate service volume. In addition to the main effects, the moderating effects of the organizational parameters are discussed.
\end{abstract}




\section{INTRODUCTION}

Accounting for $60 \%$ of U.S. industrial production in 2001 (Federal Reserve 2002), durable manufactured products require added services as they advance through their life cycles. Rapid technological changes, diminishing product life cycles, and fast time-to-market requirements pressure many manufacturers in their efforts to remain competitive (Goffin 1998; Homburg, Hoyer, and Fassnacht 2002), and product innovation by itself no longer is sufficient to guarantee business success. Thus, extending durable products with related support/field services seems to make sense in terms of gaining and maintaining competitive advantage (Nambisan 2001). In response, some manufacturers - including Caterpillar, Hewlett-Packard, IBM, Philips Medical Systems, Siemens, and Xerox - seek to be successful total solution providers; i.e., achieve superior product sales than competitors (relative product sales) and increase the importance of service revenues as a percentage of total turnover (service volume).

Although the importance of services in Western economies has been acknowledged and documented, and despite the clearly compelling need to acquire fine-grained, research-based insights into this aspect of manufacturing competitiveness, no empirical research investigates the effects of organizational parameters (i.e., organizational characteristics; Homburg, Hoyer, and Fassnacht 2002) and a service business orientations on the ability of manufacturing firms to increase relative product sales and service volume. Cespedes (1994), Goffin (1998), Homburg, Hoyer and Fassnacht (2002), Nambisan (2001), and Mathieu (2001) express the importance of a service business orientation for manufacturing firms, but though previous studies identify which organizational parameters facilitate a service business orientation in banking (Lytle, Hom, and Mokwa 1998) and retailing (Homburg, Hoyer, and Fassnacht 2002), no such study extends these investigations to the manufacturing sector. 
Therefore, on the basis of (fragmented) literature, and facilitated by semi-structured indepth interviews, we develop an integrated theoretical model that regroups the direct and interaction effects of organizational parameters and service business orientation on relative product sales and service volume in manufacturing industries. Based on the extant literature and contemporary business practices, we distinguish between two types of service business orientations: (1) services in support of the product (SSP) and (2) services in support of the client's actions (SSC) (Mathieu 2001).

The following research objectives guide the present study:

- $\quad$ RO1: Which organizational parameters significantly increase service business orientations in manufacturing companies?

- $\quad$ RO2: Do different service business orientations influence (a) relative product sales and (b) service volume equally?

- $\quad$ RO3: Are the relationships between service business orientations and (a) relative product sales and (b) service volume moderated by organizational parameters?

Our intended contribution is threefold. First, to identify the core issues for manufacturing companies addressing service business orientations. Second, to demonstrate that different service business orientations have different consequences on relative product sales and service volume. Third, to observe how the organizational support influences the impact of service business orientations.

\section{RESEARCH FRAMEWORK AND HYPOTHESES DEVELOPMENT}

To study the influence of services, researchers take a variety of approaches but have yet to integrate these within the manufacturing sector. For example, one approach identifies organizational behavior in terms of support for specific organizational parameters that indicate a company's service orientation, defined as the organization's acceptance of 
"enduring organizational policies, practices, and procedures intended to support and reward service-giving behaviors that create and deliver services excellence" (Lytle, Hom, and Mokwa 1998, p. 459). This interest in service orientations is relatively new, emerging initially when Bowen, Siehl, and Schneider (1989) called for research comparing characteristics of service and manufacturing companies. More recently, service orientation research has even extended to team and corporate levels in banking (Lytle, Hom, and Mokwa 1998) and retailing (Homburg, Hoyer, and Fassnacht 2002). Alternatively, some research considers the level of service orientation of the business practices (Homburg, Hoyer, and Fassnacht 2002), that is, the service business orientation.

However, according to contingency theory (Hofer 1975), these approaches are interdependent, because companies must deploy organizational resources to support their service business orientation (Homburg, Hoyer, and Fassnacht 2002). Therefore, manufacturers must understand which organizational parameters facilitate their service business orientation, as well as if and how these parameters affect the relationship between the service business orientation and relative product sales or service volume. In order to identify relevant and important organizational parameters, which should significantly increase service business orientation (RO1), we built on organizational service climate literature. A climate for service is "one in which a descriptive set of characteristics (parameters) concerning service delivery and service quality differentiate an organization from others and result in service related behavior of the individuals in the organization" (Lytle, Hom, and Mokwa 1998, p. 457; Kelley 1992).

Adopting a contingency perspective, we postulate that a set of organizational parameters will foster support for a service business orientation. In order to develop our research framework on the basis of the existing literature (Appendix A), we conducted semi-structured in-depth interviews with seven service managers in the medical equipment, electronics 
manufacturing, machinery and heavy equipment, and information technology industries ${ }^{1}$.

Based on these in-depth interviews, we assess the importance of support services and gain the voice of the market regarding the organizational parameters ('General Themes' of Appendix

A) and business orientations implemented to support service offerings in manufacturing companies. We refer to these interviews throughout our framework and hypotheses development.

\section{Focal Constructs: Two Service Business Orientations}

Homburg, Hoyer, and Fassnacht (2002) demonstrate that a service business orientation consists of three dimensions: (1) the number of services offered, (2) the number of customers that are offered the service, and (3) the company's proactive emphasis of the service. We consider this conceptualization valid for several reasons. First, these dimensions are based on an extensive and rigorous analysis (Homburg, Hoyer, and Fassnacht 2002, pp. 88-89). Second, related to the definition of business orientation proposed by Walker, Boyd, and Larréché (1999), this conceptualization encompasses the breadth (number of services offered), emphasis (relative number of customers to whom the service is offered), and desired levels of accomplishment (proactiveness) of the offer. Third, conceptualizing service business orientation as consisting of these three dimensions reflects existing business perceptions. For example, managers perceive IBM as actively supporting service business orientation because it offers varied support services and has gained significant expertise by selling services to many customers around the globe. Also, IBM's mission statement makes its proactiveness clear: "We translate advanced technologies into value through professional solutions, services, and consulting businesses worldwide" ( $\underline{\text { www.ibm.com }}$ ).

\footnotetext{
${ }^{1}$ We note that in-depth-interviews with managers have previously been carried out in order to identify organizational parameters affecting service quality (Zeithaml, Berry, and Parasuraman 1988).
} 
Regarding the number of services offered by manufacturing companies, we note the distinction between services in support of the supplier's product (SSP) and those in support of the client's actions (SSC) (Mathieu 2001). SSP are identified by Mathieu (2001) as "product services"; i.e., services which are delivered to support the installation, use, and brokering of a tangible product. These are services such as product maintenance, installation, inspection, monitoring, repair, recycling, and brokering. SSC are "services as a product"; i.e., services which a customer may experience without purchasing the tangible product. These are services such as financing, process-oriented training, business-oriented consulting, and other management services. SSC could be labeled as intellective services aimed at bringing knowledge to, and/or managing knowledge for, the customer. For instance, in 2001, FIAT Business Solutions and IBM Italy created a joint venture to deliver IT services. In 2005, IBM and the FIAT Group signed a $\$ 270$ million/year deal for a nine-year period to continue the joint offer of IT solutions. Delivering IT solutions is a process-oriented service, which does not require that FIAT customers buy a fleet of commercial vehicles. According to the dimensions outlined by Lovelock (1991), namely, the nature and recipient of services, the relationship between the firm and customers, and the level of service customization, SSC contrasts with SSP in that it represents an intense relationship between the seller and the buyer, a high degree of customization, and an emphasis on people as recipients (Mathieu 2001). In contrast, SSP, such as repair and maintenance, tend to be more standardized and call for less intense relationships with the recipients than, for example, process-oriented consulting, which must involve customers' specific logistics needs. Maintaining a Xerox copier sold to any customer requires standardized procedures, but delivering customized solutions requires an intense relationship with the recipient and a good understanding of how the product fits the customer's logistics. When Vanderlande Industries, a Dutch company that designs and manufactures automated material handling systems, sold a baggage handling 
solution to Boston's Logan International Airport in 2002, the company had to understand the airport's logistics and develop closer relationships to customize and co-create the new turnkey system. Because SSP and SSC differ in nature (tangibility of the recipient, cocreation, and relationship intensity), we contrast them with previous findings regarding the leveraging power of services for product sales, as proposed by Grönroos (1998). Therefore, we refer to the SSP and SSC business orientations of manufacturing companies and observe their consequences on performance measures.

\section{Consequences of Service business orientations}

\section{Relative Product Sales}

Relative product sales represent the extent to which manufacturing companies attain market share and generate sales volume by commercializing their products relative to their competitors (Hultink and Atuahene-Gima 2000). Augmenting tangible products with support services appears to increase both customer satisfaction and perceived product quality (Grönroos 1998), but we postulate that the SSC and SSP business orientations have different effects on relative product sales.

Service offerings, because of the interactivity between the supplier and the customers, and service support in the organization through the adaptation of organizational parameters, can create long-term relationships. Manufacturers that pursue more long-term relationships with customers likely prompt greater relative customer satisfaction and loyalty (Morgan and Hunt 1994). Manufacturers with an SSC business orientation can provide industrial buyers with tailored process- or business-oriented expertise to optimize the use of their own manufactured goods. Additionally, the nature of the relationship with prospect or current SSC customers provides the supplier with ample opportunities to explore the customer's activity cycle (Kumar 2004), and gather specific information on current or future needs for manufactured 
products. In other words, an SSC business orientation creates customer intimacy between manufacturers and customers, enabling them to (a) exchange specific knowledge, (b) develop closer relationships, and (c) co-create value. Therefore, we posit that an SSC business orientation will improve relative product sales.

It is commonly accepted in literature though that creating a competitive advantage with services is challenging due to services' unique characteristics (Zeithaml and Bitner 2000). Most of the essential requirements for the sustainability of the competitive advantage such as rarity, imperfect imitability, and a lack of equivalent substitutes are more difficult to satisfy for services than for products (Matthyssens and Vandenbempt 1998). This is especially true for SSP, which are less specific, less customized, and less knowledge-intensive than SSC are (Mathieu 2001). Today, industrial manufacturers have become quite active in providing such services (Oliva and Kallenberg 2003): e.g., 'Xerox Support', 'Philips Product Solutions', 'Boeing Lifecycle Support', 'Dell Technical Support', and 'Airbus Global Support'. As SSP offerings spread throughout the manufacturing industries, their distinctiveness erodes. In many industries, SSP become minimum requirements; i.e., core offerings which are necessary to participate in the market. SSP can thus be identified as product failure preventers rather than product success producers (Varadarajan 1985). Also, manufacturers often cannot differentiate their SSP on the basis of service quality. According to the services director of a medical equipment manufacturing firm, companies such as Agfa Medical, General Electric, Philips, and Siemens, have all "attained undifferentiated levels of quality for 'basic' services." Indeed, these more standardized services offerings have fewer customization possibilities and less relationship intensity, which are both important to business customers (Mathieu 2001). In other words, we argue that the competitive equally which has reached many manufacturing products (Grönroos 1998) should have also spread to SSP. Hence, SSP are more tickets to 
right than tickets to heaven (Anderson, Narus, and van Rossum 2006) and are therefore less likely to create relative product advantages for the supplier.

Hla: A greater emphasis on an SSC business orientation increases relative product sales. H1b: There is no significant relationship between an SSP business orientation and relative product sales.

\section{Service Volume}

Several authors (e.g., Grönroos 1998) suggest that many manufactured-goods companies have currently reached competitive equality. Indeed, the manufacturing companies experience increasing difficulties in maintaining technological superiority and maintaining low prices is equally challenging as a differentiation strategy (Zeithaml and Bitner 2000). This seems to suggest that there could be an important shift in the composition of manufacturing companies' turnover. Service volume is defined as the importance of service revenues as a percentage of total turnover. Given findings from other researchers who debated the difficulties of measuring economic returns such as service profitability (Anderson, Fornell, and Lehmann 1994), service volume appears as valid indicator for empirically establishing the relative importance of services in the manufacturing firms' overall market performance.

While it seems increasingly difficult to generate higher product turnover (Zeithaml and Bitner 2000), manufacturing companies are facing increasing demands for industrial services (Madrid 2003) ${ }^{2}$. Because the market for industrial services is healthy and growing (Arabe 2004), many manufacturers are increasing their service offerings or entering the service market ${ }^{3}$. In view of these market conditions, the market for SSP and SSC should be less pricecompetitive, and enables suppliers not only to supply value to their customer base, but also to capture an economic rent on these services. Moreover, service intangibility hinders pricing transparency and comparison (Walker, Boyd, and Larréché 1999). The service manager of the

\footnotetext{
${ }^{2}$ We test (and confirm) that manufacturers in our sample are experiencing increasing demand for services.

${ }^{3}$ We test (and confirm) that manufacturers are confronting increasing offers of services by competitors.
} 
IT manufacturing sector confirms: "There is competition on price like in most markets of course, but at this moment, service pricing is still not fully transparent and quite difficult to compare." Thus, the proactive supply of a broader service range to more customers is expected to increase service revenues. Based on prior literature and current market conditions, we argue that the higher SSP and SSC business orientations are the higher service volume will be. Therefore, we hypothesize:

H2a: A greater emphasis on an SSC business orientation increases service volume. H2b: A greater emphasis on an SSP business orientation increases service volume.

\section{Organizational Parameters}

Service components represent "a combination of processes, people skills, and materials that must be appropriately integrated to result in planned or designed service" (Goldstein et al. 2002, p. 121). Because of its intrinsic properties, services can be highly complex. The resources needed to support service offerings, and the resulting complexity of the overall offering (tangible products and intangible services), create functional interdependencies that require effective management (Cespedes 1994). Thus, effective service companies rely on climatic and cultural mechanisms, such as shared service norms and values (Bowen, Siehl, and Schneider 1989). This holds important implications for the organization and its employees, in that "the emphasis of the business model changes from transaction- to relationship-based" (Oliva and Kallenberg 2003, p. 161). Therefore, building on widely referenced articles in the field of organizational service climate as presented in Appendix A, as well as on our interviews, we identify relevant organizational parameters and argue that the relationships among the latter, service business orientations, and their consequences require clarification if they are to guide manufacturing companies in establishing and profiting from service business orientations. 


\section{Identifying Relevant Organizational Parameters for the Manufacturing Industry}

Based on our qualitative findings, the most complete framework to identify the relevant organizational parameters involves the one developed by Lytle, Hom, and Mokwa (1998). Following a comprehensive theoretical review, and using a solid research design (i.e., focus group interviews, multiple rounds of pre testing, multi sample assessment, and multi industry replications; however excluding the manufacturing setting), these authors developed a comprehensive measure (SERV*OR) that evaluates an organization's service orientation. In practice, six organizational parameters from the service climate literature emerged during our in-depth interviews. These parameters are: (1) top management's commitment to and visionary leadership of services, (2) service rewards, (3) service technology, (4) crossfunctional communication of service employees, (5) service training, and (6) customer treatment. The framework developed by Lytle, Hom, and Mokwa (1998) is the sole framework, which alone regroups all six parameters identified during the in-depth interviews); this confers unique value (and reliability) to these findings. Also and further explained in the methodology section, the measures developed by Lytle, Hom, and Mokwa (1998) received the most fervent support from managers a propos their comprehensiveness and clarity. Appendix A provides selected quotes from our interviewees regarding these factors; Figure 1 depicts the resulting framework that is developed below.

\section{[Insert Figure 1 about here]}

\section{Top Management's Commitment to and Visionary Leadership of Services}

According to Sureshchandar, Rajendran, and Anantharaman (2001, p. 382), "service leadership is the art of leading and espousing a mental, strategic, and spiritual change in the organization and simultaneously initiating and accomplishing practical changes and ensuring 
that they are systems and measures." The innovation management literature shows that top management assumes an important role in the creation of organizational integration (Millson and Wilemon 2002), the intraorganizational diffusion of technology (Pae et al. 2002), and its overall contribution to new product success (Souder and Jenssen 1999). The social influences of top management on service business orientations can be explained by two mechanisms: the normative influence of top management on employees' behaviors and the belief of employees in top management (Venkatesh and Davis 2000). In a manufacturing setting, where the development of service business orientations may not be viewed as the core activity, the commitment of top managers to the service orientation of their company becomes very important. A business reorientation, i.e., towards a higher service orientation, redistributes power. People may protect the value of their existing competencies and oppose valuable changes. However, even if employees are not favorable to performing a behavior, they will be pressured to do so if key referents think they should (Ajzen and Fishbein 1989).

Top management commitment and vision should also moderate the relationship of the SSC business orientation with service volume and relative product sales. Earlier research on Total Quality Management demonstrates a significant interaction effect between the leadership style of top management and the process management of its employees (Samson and Terziovski 1999). Top management commitment and vision motivates and enables employees to further integrate services in the organization (Millson and Wilemon 2002). Since SSC tend to be customized and directed at a client, the variability of SSC-processes is expected to be higher than that of SSP-processes, which are standardized and in support of the product. This causes the outcome of SSC delivery to be very dependent on employees' performance. Therefore, higher top management commitment to services will stimulate employees to increase the revenue generated by an SSC business orientation and its share in total turnover (e.g., through higher prices for better services), and enable and motivate them to sell more of their 
company's core products to prospects and current customers (e.g., in a bundled solution). Therefore, we posit:

H3a: Greater top management commitment to and visionary leadership of services leads to greater emphasis on (1) SSP and (2) SSC business orientations.

H3b: The relationships between an SSC business orientation and (1) relative product sales and (2) service volume are stronger when top management's commitment to and visionary leadership of services is stronger.

\section{Service Rewards}

People are important in new service development processes (Johnson 1996). Manufacturing firms wishing to create employee commitment to service business orientations may find it beneficial to redirect their reward policy accordingly. Social exchange theory (Cook and Whitmeyer 1992) argues that reciprocity provides an important lever in the accomplishment of organizational objectives. "Positive, beneficial actions directed at employees by the organization and/or its representatives contribute to the establishment of high quality exchange relationships that create obligations for employees to reciprocate in positive and beneficial ways" (Settoon, Bennett, and Liden , 1996, p. 219). Greater service rewards will encourage employees to reciprocate by developing and supporting service business orientations.

Reward systems influence the resource allocation processes and decisions of employees (Stonich 1981). The influence of such systems materializes, for example, in faster reactions to customer queries. In turn, a more effective and efficient management of resources will lead to higher returns, and ultimately, to higher employee rewards. Stonich (1981, p.346) described this productive cycle as the "strategic management cycle". Hence, we expect that the relationship between the service orientation and service volume will be stronger when rewards are greater. This moderating effect can only be posited between service orientations and service volume given that rewards on an 'object' leads to more efficient and effective 
resource allocations for the 'object' in question. The physical and psychological inseparability of producers (i.e., service employees) and consumers of a service (Bowen and Schneider 1988) reinforces our hypothesis that appropriate reward policies can positively affect the relationship between service business orientations and the percentage of total turnover generated by service revenues. Our semi-structured interviews also corroborate previous findings in organizational behavior literature: HR practices significantly affect the quality, and therefore the billability, of the service offering. In manufacturing cultures, with their focus on cost efficiencies and economies of scales (Jelinek and Goldhar 1983), rewards for service behavior may get overlooked. However, by rewarding such behaviors, manufacturers emphasize the importance of services, thus creating a favorable service philosophy among employees. Therefore, we posit:

H4a: Greater service rewards leads to greater emphasis on (1) SSP and (2) SSC business orientations.

H4b: The relationships between (1) SSP and (2) SSC business orientations and service volume are stronger when service rewards are greater.

\section{Service Technology}

In a manufacturing organization, the most common characterizations of technologies are "functions of the equipping and sequencing of workflow activities" (Mills and Moberg 1982, p.470). In contrast, service technologies "typically are described as knowledge technologies" (Mills and Moberg 1982, p.470). The IT architecture is indeed an important enabler of an excellent service system (Zeithaml and Bitner 2000). Service providers that introduce new services more rapidly, tend to have significantly better control over their IT infrastructures (Froehle et al. 2000), which they use to build an excellent service system (Zeithaml and Bitner 2000

The use of service technologies has two consequences for manufacturing organizations. First, service technologies serve as a market orientation tool (Narver and Slater 1990; Arabe 
2004). Customer databases, for example, enable firms to collect, process, and send information effectively (Nonaka and Teece 2001). The collection and transfer of customer information within the organization helps manufacturers to proactively plan their services offering. Second, service technologies are expected to influence the relationship between SSP and SSC business orientations and service volume. With more data about customers and the use of appropriate software to manage their relationships with customers, manufacturers are able to manage their time and resources more effectively and efficiently (Zeithaml and Bitner 2000). For instance, service technologies enabled the Social Security Administration in the U.S. to realize dramatic service delivery improvements (McDonough and Buckholtz 1992). The contemporary expectations concerning speed, personal recognition, and 24-hour service of business customers often requires the assistance of sophisticated and integrated technologies (Lytle, Hom, and Mokwa 1998). Also, the use of service technologies helps manufacturers to increase the tangibility of their service offerings (and expertise), which should ultimately increase customers' willingness to pay for those services and, ultimately, their share in the manufacturer's total turnover (Zeithaml and Bitner 2000).

This duality of technology's role has been described as 'technology-facilitation' (Froehle 2006). The feedback immediacy enabled by the technology, or synchronicity, permits rapid updates and clarifications of the information conveyed and the tasks performed (Froehle 2006; Arabe 2004; Zeithaml and Benter 2000). Therefore:

H5a: Greater use of service technology leads to greater emphasis on (1) SSP and (2) SSC business orientations.

H5b: The relationships between (1) SSP and (2) SSC business orientations and service volume become stronger with greater use of service technology.

Cross-Functional Communication between Service Employees and the Rest of the Firm 
The literature on cross-functional teams convincingly demonstrates that internal functional boundaries must disappear if employees are to profit from one another's expertise and insights. Essentially, cross-functional communication refers to "interdependency and information sharing between the various organizational units" (Song, Montoya-Weiss, and Schmidt 1997, p. 37). Cross-functional communication has been linked to the effectiveness of new product and service development (Lievens and Moenaert 2000), product quality (Menon, Jaworski, and Kohli 1997), product innovativeness (Sethi, Smith, and Park 2001), and the ability to cope with complex and dynamic environments (Huber 1982). Communication across functions enhances the collective learning and efforts needed to reach common goals (Atuahene-Gima and Evangelista 2000). For a company such as Xerox to understand the services customers require and the proactiveness needed, various departments must communicate (e.g., sales, marketing, installation, and customer service). Organizations cannot truly leverage service offerings when they isolate the service orientation within the boundaries of the service department. Service norms, values, and inputs must span the entire firm to optimize combinations of processes, people, and materials (Goldstein et al. 2002).

In their framework on service orientation, Lytle, Hom, and Mokwa (1998) refer to the communication of service 'standards'. However, our interviews demonstrate that crossfunctional communication entails much more (Appendix A). In fact, a department's importance in an organization can be assessed by its centrality in the communication flows (Achrol 1997). The frequency of cross-functional communication between service employees and the rest of the firm is an important organizational parameter. Such communication improves overall service awareness in the organization.

Cross-functional communication is also expected to moderate the relationship between an SSC business orientation and relative product sales. More frequent communication between service personnel and other employees enables manufacturers to better integrate, bundle, 
contextualize, and customize their SSC business orientation to product offers and achieve greater relative product sales. Indeed, the nature of the supplier/customer-interface makes it possible for service employees to gather detailed information regarding the opportunities provided by combining services such as financing and process- or business-oriented training with manufactured products (Mathieu 2001). The moderating role of cross-functional communication is well embedded in the resource-based view (Srivastava, Fahey, and Christensen 2001), which suggests that combining heterogeneous knowledge and competences within the organization leads to a higher relative product sales. Some even define core competences with explicit reference to cross-functional communication: "[c]ore competence is communication, involvement, and a deep commitment to working across organizational boundaries" (Prahalad and Hamel 1990, p. 82). Therefore, we hypothesize:

H6a: The more cross-functional communication between service employees and the rest of the firm, the greater the emphasis on (1) SSP and (2) SSC business orientations.

H6b: The relationship between an SSC business orientation and relative product sales is stronger when cross-functional communication between service employees and the rest of the firm is more frequent.

\section{Service Training and Customer Treatment}

Service training and customer treatment represent the quality of the service delivered in the mind of customers (Lytle, Hom, and Mokwa, 1998). The importance of both parameters is embedded in the producer-customer relationship (Lovelock 1991).

The literature on organizational service climate does not explicitly differentiate the roles of service training and customer treatment from other organizational parameters. However, building on our exploratory interviews and the service quality literature (Zeithaml and Bitner 2000), we define service training and customer treatment as variables moderating the relationship between SSP/SSC business orientations and service volume. 
First, by effectively training service personnel, manufacturers increase the likelihood of “first time right". Training includes quality-based team training, problem-solving training, and inter-personal skills training (Lylte, Hom, and Mokwa 1998; Martocchio and Judge 1997), which will positively influence the effectiveness and efficiency of SSP and SSC delivery. In the case of SSC delivery, possessing the appropriate soft skills and the capacity to optimally assimilate customer information, improves the manufacturer's ability to generate a higher service volume. For SSP delivery, service training is expected to increase service responsiveness and reliability.

Second, customer treatment during service encounters is both essential and central (Bowen and Schneider 1988), because of the inseparability of the provider and the client. When employees deliver quality service and go out of their way for customers, it reflects the manufacturer's service orientation and affects the relationship between SSP and SSC business orientations and the percentage of total turnover generated by service revenues. Customer treatment determines customers' perceptions of service performance (Zeithaml and Bitner 2000) and their willingness to pay for the service. Indeed, customer treatment - or customercentric relationships (Vargo and Lusch 2004) - "is a promise and assurance that the exchange relationship will yield valuable service provision, often for extended periods" (p. 12). Therefore, we posit that:

H7: The relationships between (1) SSP and (2) SSC business orientations and service volume are stronger when employees receive more service training.

H8: The relationships between (1) SSP and (2) SSC business orientations and service volume are stronger when customers receive better treatment. 


\section{Data Collection}

We collect the data using survey research. Following the qualitative exploratory phase, we developed a questionnaire, and then contacted 15 companies to participate in the pretest. Respondents to the pretest indicated whether they could answer our questions and if the survey needed to be clarified. Five services required clarifications, which we provide in parenthesis in the right-hand column of Appendix B.

For the empirical data, we collect responses from manufacturing firms located in Belgium, the Netherlands, and Denmark that represent seven industry segments: heavy machinery (including heavy medical equipment), automotive manufacturing, construction, electrical manufacturing, manufacturing of heavy and precision electronics, IT and telecom, and mechanical manufacturing. We select these segments in line with the listing of manufacturing industries used by the European Commission and Financial Times.

In Belgium, we contacted 211 manufacturers and provided service managers an e-mail with a link to our survey, which was professionally translated and back-translated into Dutch, English, and French (Brislin 1980). After we sent two e-mail reminders, we received 56 completed online surveys (26.5\%). In the Netherlands, we again e-mailed the survey, and respondents could answer it in Dutch or English. In Denmark, due to time and financial constraints, the survey appeared only in English, which is the working language in most companies. This procedure resulted in 54 responses from the Netherlands (19.9\%) and 41 from Denmark (19.6\%). In total, we received 151 surveys from service managers, directors, and vice presidents of manufacturing firms. Due to the nature of our study, we exclude 14 companies that fully outsource their services, leaving us with a sample of 137 usable questionnaires.

We compare early (first 75\%) and late (last 25\%) respondents according to Amstrong and Overton's (1977) recommended procedure and find no differences in terms of support for 
service orientations, relative product sales, or service volume, so non-response bias is not an issue. We also test whether we can pool the data across the three countries. The support for SSP and SSC business orientations (SSP: $F=1.13, p>0.05$; SSC: $F=0.04, p>0.05$ ), relative product sales $(F=0.06, p>0.05)$, and service volume $(F=2.36, p>0.05)$ do not differ significantly across countries, so we may pool the data.

Each respondent answered the survey in reference to products commercialized in and practices related to the firm's primary industry segment, which we define as the segment that generates most of the net sales or contract revenues for the company. All managers received an executive summary of the findings, as well as a chance to compare their performance with that of others in the same industry segment. We also assured respondents' confidentiality.

\section{Model Testing: A Nested Model Approach}

To test the conceptual model (Figure 1), we implement a nested model approach, with which we can compare model fit among three models of increasing complexity. The basic model (model 1) tests the relationships between the antecedents and outcomes of service business orientation, without moderating effects. In model 2, we include the interaction effects between service business orientations and their antecedents on the outcome variables. We then test the full model, as presented in Figure 1. In the following sections, our discussion focuses on the most complex model (model 3), because findings pertaining to the other two, less complex models demonstrate a weaker goodness of fit (Tenenhaus, Vinzi, Chatelin, and Lauro 2005) and would not render significant moderation effects (Table 3).

\section{Measurements}

We use PLS-Graph Version 3.0 (Chin 2001) to obtain partial least square (PLS) estimates for both the measurement and the structural parameters for structural equation modeling (SEM) 
(Chin 1998; Hulland 1999). A component-based SEM approach, PLS path modeling does not require multivariate normal data, places minimum requirements on measurement levels, and is more suitable for small samples (Chin 1998; Fornell and Bookstein 1982; Hulland, 1999; Tenenhaus et al. 2005). Moreover, PLS can accommodate the use of formative indicators more easily than covariance-based SEM (Chin 1998; Hulland 1999), and PLS path modeling is more appropriate for models that contain complex relationships (e.g., moderating effects, Chin, Marcolin, and Newsted 2003; many latent and manifest variables, Chin 1998; see Figure 1). To ensure an adequate sample size, we conducted a power test, as proposed by Cohen (1988), for the $F$-test and relate the $R^{2}$ of the endogenous constructs. Assuming a medium effect size $\left(f^{2}=0.15 ; R^{2}=0.13\right)$ for our predictors of service volume, a significance level $(\alpha)$ of 0.05 and a desired power $(1-\beta)$ of 0.80 would require a sample size of 126 . This figure is within the bounds of the sample size we obtained.

We use existing scales or measures adapted from existing scales, as we list in Appendix C, which we chose because they had been used in previous studies of service orientation (i.e., Homburg, Hoyer, and Fassnacht 2002; Lytle, Hom, and Mokwa 1998). Except for crossfunctional communication and top management's commitment to and visionary leadership of services, all other measures of organizational parameters were borrowed from Lytle, Hom, and Mokwa (1998). The reasons for choosing other measures for cross-functional communication and top management's commitment to and visionary leadership of services are the following: (1) cross-functional communication appeared as a broader construct than that proposed by Lytle, Hom, and Mokwa (1998); (2) managers did not approve of their scale for top management's commitment to and visionary leadership of services. Therefore, the latter organizational parameters, as well as our dependent measures, were selected on the basis of their extent of use in previous research, comprehensibility to managers, and reported reliability and validity. As we note Appendix D, only the scales we use to measure service 
business orientation are formative, whereas the rest are reflective. A service business orientation is conceptualized in terms of three aspects: the number of (Appendix B), the broadness of, and the emphasis on services. Because we gather information across industries, we require a list of core SSP and SSC that fit every manufacturing industry, so we verify that at least one firm in each industry segment offers each field service on the list. To build this list, we consulted work by Homburg, Hoyer, and Fassnacht (2002), Lovelock (1983, 1991), Mathieu (2001), and Oliva and Kallenberg (2003), as well as our interviews with customer service managers. For each of 20 different services identified, we asked whether it is offered $(0=$ "not offered", $1=$ "offered"). If the corresponding service is offered (for instance "repair services'), we asked the number of customer who are offered repair services (broadness) (on a seven-point Likert-type scale), and the extent to which the service is emphasized to the customers (emphasis) (on a seven-point Likert-type scale). Because the number of services is additive (0-12 for SSP, 0-8 for SSC), we convert this measure to a seven-point scale similar to that used for broadness and emphasis. Other variables defining the formative construct (i.e., the broadness of and emphasis on services) are then calculated as a mean of the corresponding items. For example, the broadness of SSP is calculated, for each manufacturing firm, as the mean of the broadness measured for all SSP offered by this manufacturer. The emphasis on SSC is calculated, for each manufacturing firm, as the mean of the emphasis measured for all SSC offered by the manufacturer. Next, using PLS, we formalize the three components of business orientation as a formative construct, which together establish support for business service orientations.

In addition, with PLS path modeling, we assess the psychometric properties of the measurement instruments, including reliability, convergent validity, and discriminant validity (Chin 1998; Fornell and Bookstein 1982; Tenenhaus et al. 2005). We test a measurement model without structural paths in PLS-Graph version 3.0 (Chin 2001), which is analogous to 
confirmatory factor analysis in covariance-based SEM. To demonstrate convergent validity, according to the factor loadings of the measures on their respective constructs (Chin 1998; Tenenhaus et al. 2005), every item should have a standardized loading that exceeds 0.5 (Hulland 1999; Peterson 2000), which exists in our data (Appendix D).

We assess the reliability of the measures using composite reliability and average variance extracted (AVE) (Appendix D). The composite scale reliabilities range from 0.910 to 0.934 , exceeding the cut-off value of 0.7 suggested by Nunally and Bernstein (1994). The AVE range from 0.669 to 0.864 , in excess of the 0.5 cut-off value proposed by Fornell, Bookstein, and Larcker (1981). We also assess discriminant validity by determining whether constructs share more variance with their measures than with other constructs in the model (Chin 1998), in which case the square root of the AVE exceeds the construct intercorrelations in the model. As Table 2 reveals, construct intercorrelations in our model do not exceed the square root of the AVE.

We include firm age and service delivery mode (fully or partly delivered) to observe whether these factors influence the dependent measures of relative product sales and service volume. Older manufacturing firms with more experience may achieve higher relative product sales and service volume, and partial service delivery by the manufacturer could grant more time and resources for product development, which may affect both relative product sales and service volume.

Finally, because we collect our data using a survey questionnaire, we check for common method variance (CMV), which may inflate the estimated relationships, using the approach of Lindell and Whitney (2001). Lindell and Brandt (2000) and Lindell and Whitney (2001) posit that the smallest correlation with a theoretically unrelated variable provides a judicious estimate of CMV, so we would need to partial out the effect of the smallest correlation $\left(\left|r_{s}\right|\right)$ for all bivariate correlations to remove this effect. However, our survey questionnaire does 
not contain such a theoretically unrelated construct, so we take a slightly different approach and select the smallest correlation among our theoretical variables $\left(\left|r_{s}\right|=0.012\right)$. We conclude that for all significant effects of the antecedents on service business orientation and their consequences on the dependent variables, the corresponding bivariate correlation coefficients remain statistically significant at $p<0.05$ after we adjust for CMV. Therefore, we conclude that the effects due to CMV are negligible.

\section{RESULTS}

\section{Sample Description}

In Table 1, we present the corpographics per industry segment. We test for differences between support for a service orientation between all pairs of industry segments (with more than 10 companies) and observe no significant differences. Furthermore, all industries report high customer demand for services $(M=5.63 ; S D=1.03)$ and extensive service offerings by competitors $(M=5.01 ; S D=1.40)$. We again observe no significant differences among industries, which confirms the overall importance of services for manufacturing firms. In Table 2, we present our findings related to the mean support, standard deviations, and correlations of our measures.

[Insert Table 1 and 2 about here]

\section{Antecedents and Consequences of Service business orientation (Model 3)}

As suggested by Chin, Marcolin, and Newsted (2003), we use PLS path modeling to estimate both the main and the interaction effects in our model (see Figure 1). To test the moderating hypotheses, we apply a two-step score construction procedure (Chin Marcolin, and Newsted 2003; supplement A), in which we explicitly estimate the latent variable scores and then 
calculate the interaction terms for inclusion in the model (Tenenhaus et al. 2005). With this method, we can test for a relatively large number of interaction effects while simultaneously correcting for measurement error (Chin, Marcolin, and Newsted 2003).

To test the effects and statistical significance of the parameters, we use a (nonparametric) bootstrapping procedure with 500 resamples to obtain standard errors for the estimates (Chin 1998, 2001), which we then use to calculate the $t$-values for the parameter estimates. As suggested by Chin, Marcolin, and Newsted (2003), we employ a nested model approach to test our hypotheses, in which we first estimate a model with the direct effects (and covariates) only and then add the interaction effects.

Overall, we find that our predictors offer good explanations for the focal constructs $\left(\mathrm{R}^{2}\right.$ for SSP business orientation $=0.263 ; \mathrm{R}^{2}$ for SSC business orientation $=0.183$ ). The direct and interaction effects of SSP and SSC business orientations explain $17.1 \%$ of the variance in relative product sales and $21.2 \%$ of the variance in service volume.

Furthermore, we find support for H1a, because a greater emphasis on an SSC business orientation leads to more relative product sales $(\beta=0.173, p<0.05)$. In addition, in support of $\mathrm{H} 1 \mathrm{~b}$, the relationship between SSP business orientation and relative product sales is not significant $(\beta=-0.029, p>0.05)^{4}$.

Hypothesis 2a, in which we postulate a positive relationship between an SSC business orientation and service volume, is not supported by our data $(\beta=-0.09, p>0.05)$, though $\mathrm{H} 2 \mathrm{~b}$ is $(\beta=0.288, p<0.05)$, which indicates that the SSP business orientation links significantly to service volume.

We find partial support for $\mathrm{H} 3 \mathrm{a}$ but no support for $\mathrm{H} 3 \mathrm{~b}$. That is, greater top management commitment to and visionary leadership of services leads to a greater emphasis on an SSP

\footnotetext{
${ }^{4}$ To confirm $\mathrm{H} 1 \mathrm{~b}$, we conducted a power test for the $F$-test and relate the $R^{2}$ of the endogenous constructs predicting relative product sales. Given the effect size $\left(f^{2}=0.29 ; R^{2}=0.22\right)$ for our predictors of relative product sales, a significance level $(\alpha)$ of 0.05 and a desired power $(1-\beta)$ of 0.80 , the sample size should be of approximately 57 (Green 1991). This figure is well within the bounds of the sample size we obtained.
} 
business orientation $(\beta=0.227, p<0.05)$ but not an SSC business orientation $(\beta=0.128, p>$ 0.05). The absence of support for $\mathrm{H} 3 \mathrm{~b}$ leads us to conclude that top management commitment does not moderate the relationship between an SSC business orientation and relative product sales or service volume.

Our findings further confirm that service rewards precede service business orientation (H4a, SSP $\beta=0.158, p<0.05 ; \operatorname{SSC} \beta=0.222, p<0.05$ ) but do not moderate the relationship between SSC and SSP business orientations and service volume (H4b, SSP $\beta=-0.027, p>$ 0.05; SSC $\beta=-0.105, p>0.05)$. Furthermore, service technology influences $\operatorname{SSP}(\beta=0.290$, $p<0.05)$ and $\operatorname{SSC}(\beta=0.242, p<0.05)$ business orientations, in support of H5a, and acts a moderator of the ability of service business orientation to create service volume, in support of $\mathrm{H} 5 \mathrm{~b}$. In the case of a greater emphasis on an SSP business orientation, we find that service technology significantly strengthens its relationship with service volume $(\beta=0.329, p<$ 0.05). In contrast, support for service technology weakens the relationship between an SSC business orientation and service volume $(\beta=-0.225, p<0.1)$.

Regarding the role of cross-functional communication of service employees, we note that it does not affect SSP or SSC business orientations directly (H6a: SSP $\beta=-0.009, p>0.05$; $\operatorname{SSC} \beta=-0.07, p>0.05)$. However, the relationship between an SSC business orientation and relative product sales grows stronger when cross-functional communication is more frequent $(\beta=0.154, p<0.05)$, in support of H6b.

Finally, we study the moderating effects of service training and customer treatment on manufacturing companies' ability to increase service volumes through SSC and SSP business orientations. We find partial support for $\mathrm{H} 7$, in that an SSC business orientation is significantly associated with service volume in the case of increased service training $(\beta=$ $0.229, p<0.05)$. However, we find no such effect for an SSP business orientation $(\beta=-0.157$, $p>0.05)$. Customer treatment also does not display a significant moderating effect between 
service business orientation and service volume (SSP $\beta=-0.08, p>0.05 ; \mathrm{SSC} \beta=-0.03, p>$ 0.05). On the other hand, we note that customer treatment has a direct effect on service volume $(\beta=0.217, p<0.05)$.

Regarding the control variables, we find no significant effects of age $(\beta$ relative product sales $=0.041, p>0.05 ; \beta$ service volume $=-0.026, p>0.05)$ or delivery mode $(\beta$ relative product sales $=-0.064, p>0.05 ; \beta$ service volume $=-0.027, p>0.05)$ on relative product sales or service volume.

\section{[Insert Table 3 about here]}

To conclude our structural analysis, we calculate the goodness of fit (GoF) of the model, in reference to Tenenhaus et al.'s (2005) global fit measure for PLS. In this context, GoF $(0 \leq$ $\mathrm{GoF} \leq 1$ ) refers to the geometric mean of the average communality; because the communality equals the AVE extracted in the PLS approach, we propose a cut-off value of 0.5 (Fornell, Bookstein, and Larcker 1981). Moreover, in line with the effect sizes for $\mathrm{R}^{2}$ (small 0.02; medium 0.13; large 0.26) proposed by Cohen (1988), we derive the following GoF criteria for small, medium, and large effect sizes: 0.1, 0.25, and 0.36. Our GoF index reaches 0.399.

\section{DISCUSSION}

This study integrates the organizational and business orientation approaches to service orientation. It identifies and assesses: (a) how organizational parameters influence the support for service business orientations and moderate their effects; (b) the relationships between two distinct service business orientations and relative product sales and service volume.

Table 4 presents the summary of the research findings. Top management's commitment to and visionary leadership of services and service rewards are pure antecedents to service 
business orientations; service technology is a quasi-moderator making it an important parameter for the development and the outcomes of service business orientations; and service training and the cross-functional communication of employees are pure moderators of the relationship(s) between service business orientations and the outcome variables. Finally, customer treatment actually has a direct effect on service volume but no moderating effect as hypothesized.

\section{Managerial Implications}

\section{Different Services, Different Effects}

A greater emphasis on a SSP business orientation increases service volume, whereas a SSC business orientation does not have a direct effect on service volume. Because they blend more naturally in product/service bundles (Mathieu 2001), the manufacturing companies in our sample probably have been offering SSP (e.g., delivery and repair), for a longer time than SSC. For example, Caterpillar started building track-type tractors in 1915 and offering repair services in the 1950s. However, it only began developing SSC in the late 1980s, and it launched its Caterpillar Logistics Services Inc. as recent as 2005. Following the learning curve doctrine (Levin 2000), Caterpillar is probably more proficient at delivering SSP than at delivering SSC. Furthermore, the supply of SSP is locked firmly into the product offering (e.g., technical after-sales and repair services). This enables Caterpillar (and similar manufacturers) to bill SSP more easily. Finally, whenever a manufacturing company offers so-called 'higher value-added services', it runs a substantive risk of entering into direct competition with professional service organization such as financial institutions (e.g., when offering financial services) or consulting firms (e.g., when offering logistics or process management services). This may drastically clip the service volume potential. 
Apparently, an SSC business orientation leverages the relative sales of industrial products, while an SSP business orientation generates service volume. These findings suggest an alternating temporality in the implementation of service business orientations. Manufacturing firms should first implement an SSC business orientation to leverage their product sales. Subsequently, they can proactively offer SSP to their customer base in order to increase service volume. To make informed decisions about an SSC business orientation, manufacturing companies can follow the strategic direction model developed by Vandenbosch and Weinberg (1994), which suggests ways to bundle products and SSC.

Overall, regarding the generation of service volume, one may conclude that manufacturing firms are not breaking even regarding the financial benefits and the strategic/political costs of implementing an SSC business orientation (Mathieu 2001). As further explained below, a defensive behavior from managers belonging to the traditional manufacturing side of the firm who may feel threatened by this business orientation could engender reluctance to such a business orientation and hinder its potential of generating significant service revenues. Our findings regarding the absence of a direct relationship between top management commitment and visionary leadership to services and an SSC business orientation discussed below may validate this argument.

\section{Nurturing a Service Business Orientation through People}

Our findings show that the role of top management commitment and vision significantly fosters the SSP business orientation of a manufacturing firm, but not its SSC business orientation. Because a manufacturing company revolves around its core product offering, top management may be less inclined to proactively promote SSC. Senior management may even resist the implementation of a SSC business orientation if the professional cultures within their firm remain dominated by $R \& D$ and operations (Pearson 1990). A professional culture 
"exists when a group of people employed in a functionally similar occupation share a set of norms, values, and beliefs related to that occupation" (Sirmon and Lane 2004, p. 310. As we explained before, business reorientation redistributes power, creating internal conflicts and resistance to change. Inviting employees to actively participate in reorganizations, and establishing trust between employees and company leadership facilitates organizational change (Lines et al. 2005). The service department may provide help in reducing potential resistance to SSC business orientations by (1) demonstrating how SSC business orientations relate to overall organizational goals, (2) defining the implementation agenda and success criteria, and (3) establishing the gains top management may obtain from supporting the SSC business orientation (Fottler 1977).

At the individual level, important differences remain between manufacturing and service tasks and routines (Bowen, Siehl, and Schneider 1989). The study shows that service rewards act as important drivers in the development of an organization's service business orientation. Thus, manufacturing firms that successfully put into practice a genuine service orientation take advantage of the reciprocity norm. This requires the communication and implementation of a consistent and total service reward strategy that integrates service-related compensation, service-related benefits, and a service-related work environment (Kaplan 2005; Goldstein et al. 2002).

Employee service training is important: the ability to generate service volume through an SSC business orientation grows significantly with more service training. To customize a service, sellers must posses the skills to listen and appeal to the purchaser. Interestingly, this is the sole instance in which the SSC business orientation of manufacturing firms is positively associated with service volume. Finally, the direct influence of customer treatment on service volume confirms previous findings (Lylte, Hom and Mokwa 1998) rather than the posited moderating effects between service business orientations and service volume. 


\section{Understanding the Role of Cross-Functional Communication}

Our study provides a more nuanced view of the influence of cross-functional communication. Despite the importance that is almost universally awarded to cross-functional communication (see e.g.: Huber 1982; Menon, Jaworski, and Kohli 1997; Sethi, Smith, and Park 2001), we find no support for the hypothesized direct effect on SSC and SSP business orientation. However, our findings do reveal an important and significant moderating effect: the SSC business orientation of a manufacturer leads to higher relative product sales in the context of higher cross-functional communication. Manufacturing firms must ensure that their R\&D staff, the salespeople involved with a particular product, and service employees share customer-specific details. This enables the manufacturer to better customize and bundle the SSC with the product.

A plausible explanation for the lack of a direct effect of cross-functional communication on SSC and SSP business orientations concerns the level of analysis. Cross-functional service communications lead to an increased awareness, understanding, and integration of a diversity of functional activities at the operational level. However, it may not directly influence the support for a service business orientation at a higher echelon in the organization. Another explanation involves the intangibility of services. When an object of communication is intangible, communication about that object becomes more difficult (Moenaert and Souder 1996). By integrating service and other functions, manufacturers may create additional difficulties when they attempt to transform service ideas into proactive service business orientations. 
In the contemporary business context, service technologies most often are inherent, constituent enablers of a firm's services. Manufacturing firms that intend to support SSP and SSC business orientations may use these technologies to their advantage. To be successful, the implementation of service technologies must be treated as a business initiative (Milligan and Smith, 2002). It is crucial that manufacturing employees, who will use the technology, perceive the technology's usefulness and feel at ease using it (Venkatesh and Davis. 2000). Using the technology to develop service business orientations should be part of employees' missions.

The use of service technologies also moderates the relationships between service business orientation and service volume. Service technologies create higher service volume with an SSP business orientation but not with an SSC business orientation. The use of service technology may not be appropriate in the context of an SSC business orientation given that these services are directed at the client and customized rather than to the product and standardized.

[Insert Table 4 about here]

\section{LIMITATIONS AND DIRECTIONS FOR FUTURE RESEARCH}

A first limitation of our study pertains to the sample of manufacturers. Although the seven industry segments do not reveal significant differences in their support for service business orientation, our data is collected in only three countries. Although the majority of manufacturers in our sample are international firms, the northern European context may have influenced the extent of support for service business orientation. National culture and economic contingencies influence corporate behavior (Varsakelis 2001), and industrial firms located in northern European may be more or less open to change than those located in other 
countries, which would suggest greater or lesser propensities toward service business orientation. Furthermore, we develop a list of SSP and SSC that could apply across industry segments, and though this list is exhaustive, studying one or a limited number of industry segments might enable greater precision. Similarly, even if we justify our conceptualization of service business orientation with a positivistic paradigm, we note that a qualitative approach to studying service business orientation had been both possible and relevant. Such an approach could have built an incorporated view of the fragmented literature on service orientations with a greater understanding of actual product-service integration and delivery. However, because we conduct our study at an organizational level, we choose a positivistic approach, so a qualitative study of the product-service interface in manufacturing firms remains a promising avenue for further research. Finally, we use a key informant method, and though we confirm our respondents are well qualified to answer the survey questionnaire, the inherent limitations of this method apply.

We offer several options for future research. First, future research should identify other antecedents of business service orientations. For example, we do not include customer demandingness or competitor service offers, though both emerge as obvious antecedents in prior research (Li and Calantone 1998; Lukas and Ferrell 2000). They may explain, along with the identified organizational antecedents we highlight, a large proportion of the variance of our focal constructs. These market-related factors could also explain the support we find for the SSC business orientation, which appeared unrelated to top management commitment. Similarly, customer and competitor orientations should directly influence service volume and relative product sales (Kahn 1996).

Second, future research should concentrate on the relationships among our focal constructs, relative product sales, and service volume. We demonstrate the moderating roles of service technology, service training, and cross-functional communication, but in-depth 
qualitative empirical studies could potentially generate more insights into the operationalization of an SSC business orientation. For example, an elaborate cost-benefit study could help manufacturers manage the value of their SSC business orientation, which is not significantly associated with increased service volume except in the case of increased service training. Also, research suggests that the novelty and perceived importance of delivering an SSC business orientation may affect the relationship between the business orientation and service volume creation (Patterson, Johnson, and Spreng 1997).

Third, instead of surveying industrial firms, researchers could ask industrial customers about their satisfaction levels with SSC service offerings, which might clarify how customers perceive value-added services and suggest improvements to the offering and delivery process. Along these lines, and with regard to increased service volume, future research should consider the influence of pricing strategies (bundle versus individual products/services), as well as the length and types of service contracts, on optimizing service volume (Kleindorfer and $\mathrm{Wu} 2003)$.

Fourth, we believe contextual factors related to market or relationship characteristics (in addition to organizational parameters) may moderate the intensity of the relationships identified between our focal constructs and their outcomes. Prior studies reveal, for example, the moderating role of market volatility on firm performance (Pine 1993). Relational aspects such as trust between the customer and the manufacturer delivering the service (Sirdeshmukh, Singh, and Sabol 2002), the frequency of their interactions, and the absence of mechanisms for resolving conflicts (Fontenot and Wilson 1997) also could play moderating roles between an SSC business orientation and service volume creation.

All of the limitations mentioned above should be kept in mind when considering our results. Despite the limitations we believe that we have made a substantial step toward 
studying organizational antecedents to and consequences of service business orientations in manufacturing companies.

\section{REFERENCES}

Achrol, Ravi S. 1997. "Changes in the Theory of Interorganizational Relations in Marketing: Toward a Network Paradigm.” Journal of the Academy of Marketing Science 25 (Winter): $56-71$.

Ajzen Icek and Martin Fishbein. 1989. “Attitude Structure and Behavior” In Attitude

Structure and Function. Eds. A. R. Pratkanis, S. J. Breckler, and A. G. Greenwald.

Hillsdale, NJ: Lawrence Erlbaum Associates.

Anderson, Eugene W, Claes Fornell, and Donald R. Lehmann. 1994. "Customer Satisfaction, Market Share, and Profitability: Findings from Sweden.” Journal of Marketing 58 (July): 53-66.

Anderson, James C., James A. Narus, and Wouter van Rossum. 2006. "Customer Value Propositions in Business Markets.” Harvard Business Review (March): 90-99.

Andrews, Tanya L. and Steven G. Rogelberg. 2001. “A New Look at Service Climate: Its Relationship with Owner Service Values in Small Business." Journal of Business and Psychology 16 (Fall): 119-131.

Atuahene-Gima, Kwaku and Felicitas Evangelista. 2000. "Cross-functional Influence in New Product Development: An Exploratory Study of Marketing and R\&D Perspectives.” Management Science 46 (October): 1269-1284.

Arabe, Katrina C. 2004. "Spending on Services Robust: Industrial Market Trends." ThomasNet Industrial News Room (November): 1-3.

Armstrong, J. Scott, and Terry S. Overton. 1977. "Estimating Non-Response Bias in Mail Surveys.” Journal of Marketing Research 14 (February): 396-402. 
Bowen, David. E. and Schneider, Benjamin. 1988. "Services Marketing and Management Implications for Organizational Behavior.” In Research in Organizational Behavior. Eds. B. M. Staw, and L. L. Cummings. Greenwich, CT: JAI Press.

Bowen, David E., Caren Siehl, and Benjamin Schneider. 1989. "A Framework for Analyzing Customer Orientations in Manufacturing." Academy of Management Review 14 (January): 75-95.

Brislin, Richard W. 1980. "Translation and Content Analysis of Oral and Written Materials." In Handbook of Cross-Cultural Psychology. Eds. H. C. Trandis and J. W. Berry. Boston, MA: Allyn and Bacon.

Cespedes, F. V. 1994. “Industrial Marketing Management: New Requirements.” Sloan Management Review 35 (3): 45-60.

Chin, Wynne. 1998. "The Partial Least Squares Approach to Structural Equation Modeling." In Modern Business Research Methods. Ed. G. A Marcoulides. Mahwah, NJ: Lawrence Erlbaum Associates.

Chin, Wynne. 2001. PLS-Graph User's Guide Version 3.0. Houston, TX: C.T. Bauer College of Business, University of Houston.

Chin, W.W., B.K. Marcolin, and P.R. Newsted (2003), "A Partial Least Squares Latent Variable Approach for Measuring Interaction Effects: Results from a Monte Carlo Simulation Study and an Electronic-Mail Emotion/Adoption Study," Information Systems Research, 14 (2), 189-217.

Cohen, Jacob 1988. Statistical Power Analysis for the Behavioral Sciences. Hillsdale, NJ: Lawrence Erlbaum Associates.

Cook K.S. and J.M. Whitmeyer. 1992. “Two Approaches to Social Structure: Exchange Theory and Network Analysis." Annual Review of Sociology 18: 109-127. 
Dietz, Joerg, Douglas Pugh, and Jack W. Wiley. 2004. "Service Climate Effects on Customer Attitudes: An Examination of Boundary Conditions." Academy of Management Journal, 47 (February): 81-92.

Federal Reserve. 2002. Industrial Production and Capacity Utilization: Table 1a. Washington DC: Federal Reserve Statistical Release.

Fontenot, Renee J., and Elizabeth J. Wilson. 1997. "Relational Exchanges: A Review of Selected Models for a Prediction Matrix of Relationship Activities.” Journal of Business Research 39 (May): 5-12.

Fornell, Claes and Fred L. Bookstein. 1982. "Two Structural Equation Models: LISREL and PLS Applied to Consumer Exit-Voice Theory.” Journal of Marketing Research 19 (November): 440-453.

Fornell, Claes, Fred L. Bookstein, and David Larcker. 1981. "Evaluating Structural Equation Models with Unobservable Variables and Measurement Error.” Journal of Marketing Research 18 (February): 39-50.

Fottler, M.D. 1977. "Management Commitment and Manpower Program Success.” Californian Management Review 19 (Spring): 71-78.

Froehle, Craig M. 2006. “Service Personnel, Technology, and Their Interaction in Influencing Customer Satisfaction.” Decision Sciences 37 (February): 5-38.

Froehle, Craig M., Aleda V. Roth, Richard B. Chase, and Christopher A. Voss. 2000.

“Antecedents of New Service Development Effectiveness: An Exploratory Examination of Strategic Operations Choices.” Journal of Service Research 3 (August): 3-17.

Goffin, Keith. 1998. “Customer Support and New Product Development - An Exploratory Study.” Journal of Product Innovation Management 15 (January): 42-56. 
Goldstein, Susan M., Robert Johnson, JoAnn Duffy, and Jay Rao. 2002. “The Service Concept: The Missing Link in Service Design Research.” Journal of Operations Management 20 (April): 121-134.

Green, Samuel B. 1991. "How Many Subjects Does It Take to Do a Regression Analysis?” Multivariate Behavioral Research 26(3): 499-510.

Grönroos, Christian. 1998. "Marketing Services: The Case of a Missing Product. Journal of Business and Industrial Marketing 13 (4/5), 322-338.

Hofer, Charles W. 1975. “Toward a Contingency Theory of Business Strategy.” Academy of Management Journal 18 (December): 784-810.

Homburg, Christian, Wayne D. Hoyer, and Martin Fassnacht. 2002. "Service Orientation of a Retailer's Business Strategy: Dimensions, Antecedents, and Performance Outcomes.” Journal of Marketing 66 (October): 86-101.

Huber, George. 1982. “Organizational Information Systems: Determinants of Their Performance and Behavior.” Management Science 28 (February): 138-155.

Hulland, John. 1999. "Use of Partial Least Squares (PLS) in Strategic Management Research: A Review of Four Recent Studies.” Strategic Management Journal 20 (February): 195204.

Hultink, Erik-Jan, and Kwaku Atuahene-Gima. 2000. “The Effect of Sales Force Adoption on New Product Selling Performance.” Journal of Product Innovation Management 17 (November): 435-450.

Jelinek, Mariann, and Joel D. Goldhar. 1983. “The Interface Between Strategy and Manufacturing Technology.” Colombia Journal of World Business 18 (Spring): 26-36.

Johnson, Jeff W. 1996. “Linking Employee Perceptions of Service Climate to Customer Satisfaction." Personnel Psychology 49 (Winter): 831-851. 
Kahn, Kenneth B. 1996. “Interdepartmental Integration: A Definition with Implications for Product Development Performance.” Journal of Product Innovation Management 13 (May): 137-151.

Kelley, Scott W. 1992. "Developing Customer Orientation among Service Employees,” Journal of the Academy of Marketing Science 20 (Winter): 27-36.

Kaplan, Stacey L. 2005. "Total Rewards in Action: Developing a Total Rewards Strategy." Benefits and Compensation Digest (August): 32-37.

Kleindorfer, Paul R and Wu, D. J. 2003. "Integrating Long- and Short-Term Contracting via Business-to-Business Exchanges for Capital-Intensive Industries.” Management Science 49 (November): 1597-1615.

Kumar Nirmalya. Marketing as strategy. Boston : Harvard Business School Press, 2004.

Levin, Daniel Z. 2000. “Organizational Learning and the Transfer of Knowledge: An Investigation of Quality Improvement.” Organization Science 11 (November/December), 630-647.

Li, Tiger. 1999. “The Impact of the Marketing-R\&D Interface on New Product Export Performance: A Contingency Analysis.” Journal of International Marketing 7 (1): 10-33.

Li, Tiger and Roger J. Calantone. 1998. "The Impact of Market Knowledge Competence on New Product Advantage: Conceptualization and Empirical Examination.” Journal of Marketing 62 (October): 13-29.

Lievens, Annouk and Rudy K. Moenaert. 2000. "New Service Teams as InformationProcessing Systems: Reducing Innovative Uncertainty.” Journal of Service Research 3 (August): 46-66.

Lindell, Michael K. and Christina J. Brandt. 2000. "Climate Quality and Climate Consensus as Mediators of the Relationship between Organizational Antecedents and Outcomes.” Journal of Applied Psychology 85 (June): 331-348. 
Lindell, Michael K. and David J. Whitney. 2001. "Accounting for Common Method Variance in Cross-sectional Research Designs." Journal of Applied Psychology 86 (February): 114121.

Lines, Rune, Marcus Selart, Bjarn Espedal, and Svein T. Johansen. 2005. "The Production of Trust during Organizational Change.” Journal of Change Management 5 (June): 221-245.

Lovelock, Christopher H. 1983. "Classifying Services to Gain Strategic Marketing Insights." In Managing Services: Marketing, Operations, and Human Resources, 2d ed. Ed. C.H. Lovelock. New Jersey: Prentice-Hall International.

Lovelock, Christopher H. 1991. "Developing Frameworks for Understanding Service Marketing”. In: Services Marketing. Ed. C.H. Lovelock New Jersey: Prentice-Hall International.

Lukas, Brian A. and O.C. Ferrell. 2000. "The Effect of Market Orientation on Product Innovation." Journal of the Academy of Marketing Science 28 (Spring): 239-247.

Lytle, Richard S., Peter W. Hom, and Michiel P. Mokwa. 1998. “SERV*OR: A Managerial Measure of Organizational Service-Orientation.” Journal of Retailing 74 (Winter), 455489.

Martocchio, Joseph J. and Timothy A. Judge. 1997. "Relationship between consciousness and learning in employee training: Mediating Influences of Self-deception and Self-efficacy.” Journal of Applied Psychology 82 (October): 764-773.

McDonough, Francis A. and Thomas J. Buckholtz 1992.’Providing better Service to Citizens with Information Tech.” Journal of Systems Management 43 (April): 32-37.

Madrid, Catherine. 2003. "The Importance of Service for Manufacturers: Conclusions of an Empirical Study.” Service Industries Journal 23 (1): 167-194.

Mathieu, Valérie. 2001. "Service Strategies within the Manufacturing Sector: Benefits, Costs and Partnerships." International Journal of Service Industry Management 12 (5): 451-475. 
Matthyssens, Paul and Koen Vandenbempt 1998. "Creating Competitive Advantage in Industrial Service.” Journal of Business \& Industrial Marketing 13 (4/5): 339-355.

Menon, Ajay, Bernard J. Jaworski, and Ajay K. Kohli. 1997. "Product Quality: Impact of Interdepartmental Interactions.” Journal of the Academy of Marketing Science 25 (Summer): 187-200.

Milligan Andy and Shaun Smith. Uncommon practice. London : Pearson, 2002.

Mills, Peter K. and Dennis J. Moberg. 1982. "Perspectives on Technology of Service Operations." Academy of Management Review 7 (July): 467-478.

Millson, Murray R. and David Wilemon. 2002. "The Impact of Organizational Integration and Product Development Proficiency on Market Success.” Industrial Marketing Management 31 (January): 1-23.

Moenaert, Rudy K and William E. Souder. 1996. "Context and Antecedents of Information Utility at the R\&D/Marketing Interface.” Management Science 42 (November): 15921610.

Morgan, Robert M. and Shelby D. Hunt. 1994. "The Commitment-Trust Theory of Relationship Marketing.” Journal of Marketing 55 (July): 20-39.

Nambisan, S. 2001. "Why Service Businesses are not Product Businesses.” Sloan Management Review 42 (4): 72-79.

Narver, John C. and Stanley F. Slater. 1990. "The Effect of a Market Orientation on Business Profitability." Journal of Marketing 54 (October): 20-35.

Nonaka, Ikugori and David J. Teece. 2001. Managing Industrial Knowledge, Creation, Transfer, and Utilization. Thousand Oaks, CA: Sage Publications.

Nunally, Jum C. and Ira H. Bernstein. 1994. Psychometric Theory. New York: McGraw-Hill. Oliva, Rogelio and Robert Kallenberg. 2003. "Managing the Transition from Products to Services.” International Journal of Service Industry Management 14 (2): 160-180. 
Pae, Jae H., Namwoon Kim, Jim K. Han, and Leslie Yip. 2002. “Managing

Intraorganizational Diffusion of Innovations: Impact of Buying Center Dynamics and

Environments.” Industrial Marketing Management 31 (November): 719-726.

Parasuraman, A. 1998. “Customer-Service in Business-to-Business Markets: An Agenda for Research.” Journal of Business and Industrial Marketing 13 (4/5): 309-321.

Patterson, Paul G., Lester W. Johnson, and Richard A. Spreng. 1997. "Modeling the Determinants of Customer Satisfaction for Business-to-Business Professional Services." Journal of the Academy of Marketing Science 25 (Winter): 4-17.

Pearson, G. 1990. Strategic Thinking. Englewood Cliffs, NJ: Prentice-Hall.

Peterson, Robert. 2000. “A Meta-Analysis of Variance Accounted For and Factor Loadings in Exploratory Factor Analysis." Marketing Letters 11 (August): 261-275.

Pine, B. J. II. 1993. Mass Customization: The New Frontier in Business Competition. Boston, MA: Harvard Business School Press.

Prahalad, C.K. and Gary Hamel. 1990. “The Core Competences of the Corporation.” Harvard Business Review 68 (May-June): 79-91.

Samson, Danny and Mile Terziovski. 1999. "The Relationship between Total Quality Management Practices and Operational Performance.” Journal of Operations Management 17 (June): 393-409.

Schneider, Benjamin, Jill K. Wheeler, and Jonathan F. Cox. 1992. “A Passion for Service: Using Content Analysis to Explicate.” Journal of Applied Psychology 77 (October): 705716.

Schneider, Benjamin, Susan S. White, and Michelle C. Paul. 1998. "Linking Service Climate and Customer Perceptions of Service Quality: Test of a Causal Model." Journal of Applied Psychology 83 (April): 150-163. 
Sethi, Rajesh, Daniel C. Smith, and C. Whan Park. 2001. “Cross-Functional Product Development Teams, Creativity, and the Innovativeness of New Consumer Products." Journal of Marketing Research 38 (February): 73-85.

Settoon, Randall P., Nathan Bennett, and Robert C. Liden. 1996. "Social Exchange in Organizations: Perceived Organizational Support, Leader-Member Exchange and Employee Reciprocity.” Journal of Applied Psychology 81 (June): 219-226.

Sirdeshmukh, Deepak, Jagdip Singh, and Barry Sabol. 2002. "Consumer Trust, Value, and Loyalty in Relational Exchanges.” Journal of Marketing 66 (January): 15-36.

Sirmon, David and Peter J. Lane. 2004. “A Model of Cultural Differences and International Alliance Performance.” Journal of International Business Studies 35 (July): 306-319.

Song, X. Michael, Mitzi M. Montoya-Weiss, and Jeffrey B. Schmidt. 1997. "Antecedents and Consequences of Cross-functional Cooperation: A Comparison of R\&D, Manufacturing and Marketing Perspectives." Journal of Product Innovation Management 14 (January) $35-47$.

Souder, William E. and Svenn A. Jenssen. 1999. "Management Practices Influencing New Product Success and Failure in the United States and Scandinavia: A Cross-Cultural Comparative Study.” Journal of Product Innovation Management 16 (March): 183-203. Srivastava, Rajendra, K. Liam Fahey, and H. Kurt Christensen. 2001. “The Resource-Based View and Marketing: The Role of Market-Based Assets in Gaining Competitive Advantage." Journal of Management 27 (6): 777-802.

Stonich Paul J. 1981. "Using Rewards in Implementing Strategy.” Strategic Management Journal 2: 345-352.

Sureshchandar, G.S., Chandrasekharan Rajendran, and R.S. Anantharaman. 2001. “A Conceptual Model for Total Quality Management in Service Organizations.” Total Quality Management 12 (May): 343-363. 
Tenenhaus, Michel, Vincenzo E. Vinzi, Yves-Marie Chatelin, and Carlo Lauro. 2005. "PLS Path Modeling.” Computational Statistics and Data Analysis 48 (1), 159-205.

Vandenbosch, Mark B. and Charles B. Weinberg 1994. "Setting the Strategic Direction in a Product-Service Firm.” Journal of Business Research 31: 117-132.

Varadarajan, P. Rajan. 1985. “A Two-Factor Classification of Competitive Strategy Variables.” Strategic Management Journal 6 (October/December): 357-375.

Vargo Stephen L. and Robert F. Lusch. 2004. “Evolving to a New Dominant Logic for Marketing.” Journal of Marketing 68 (January): 1-17.

Varsakelis, Nikos C. 2001. "The Impact of Patent Protection, Economy Openness and National Culture on R\&D Investment: A Cross-Country Empirical Investigation.” Research Policy 30 (August): 1059-1068.

Venkatesh, Viswanath and Fred D. Davis. 2000. "A Theoretical Extension of the Technology Acceptance Model: Four Longitudinal Field Studies.” Management Science 46 (February): 186-204.

Voss, Christopher A., Aleda V. Roth, Eve D. Rosenzweig, Kate Blackmon, and Richard B. Chase. 2004. “A Tale of Two Countries' Conservatism, Service Quality, and Feedback on Customer Satisfaction.” Journal of Service Research 6 (February): 212-231.

Walker, Orville C., Harper W. Boyd, and Jean-Claude Larréché. 1999. Marketing Strategy: Planning and Implementation, 3d ed. New York: McGraw-Hill.

Zeithaml, Valarie A., Leonard L. Berry, and A. Parasuraman. 1988. "Communcation and Control Processes in the Delivery of Service Quality." Journal of Marketing 52 (April): $35-48$.

Zeithaml, Valarie A. and Mary Jo Bitner. 2000. Service Marketing: Integrating Customer Focus across the Firm. New York: McGraw-Hill. 
FIGURE 1: Antecedents to and Consequences of Service Business Orientations

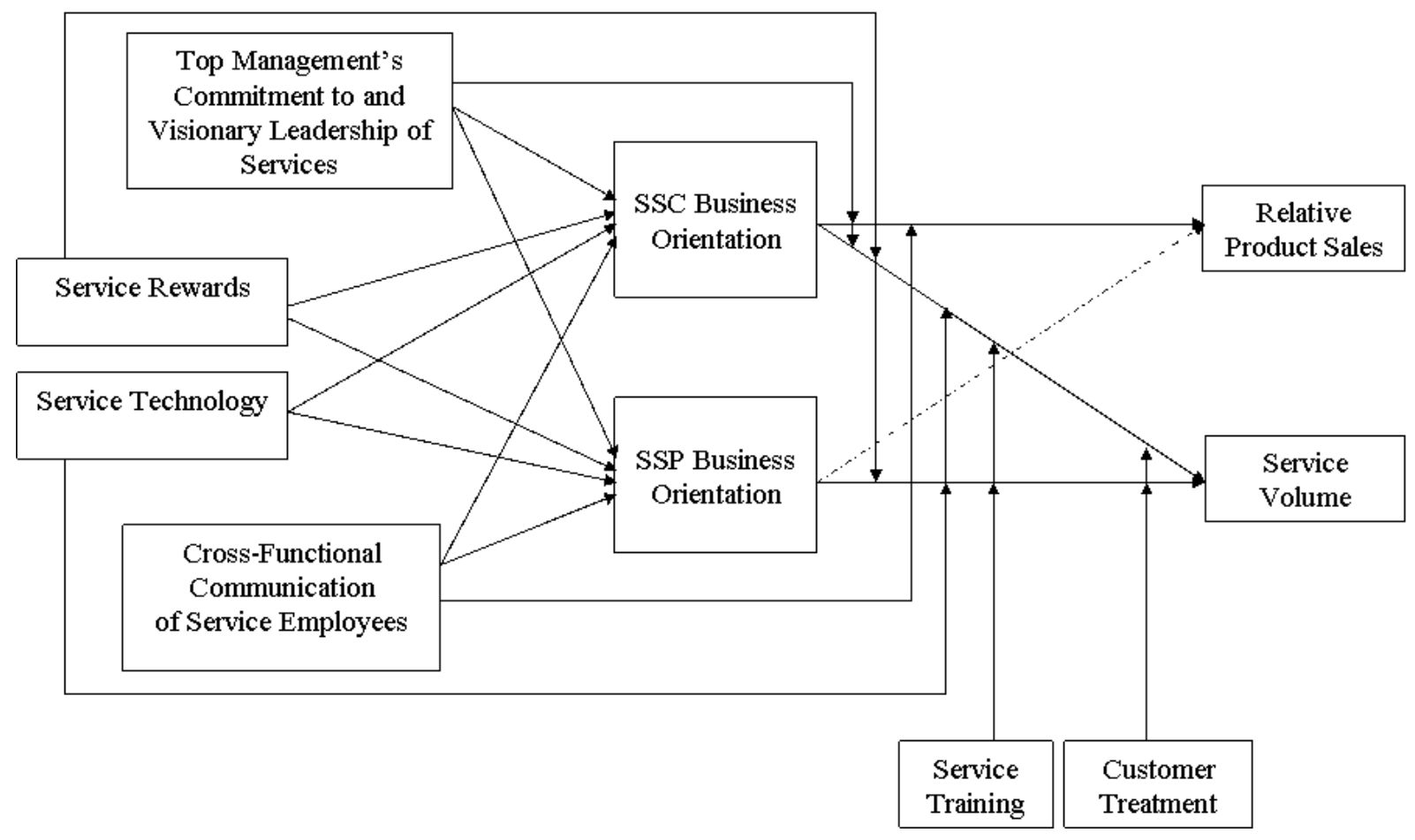

$-\cdots \quad$ : This relationship is hypothesized to be non significant 
TABLE 1: Description of the Manufacturers per Industry Segment

\begin{tabular}{|c|c|c|c|c|c|c|c|c|}
\hline & Machinery & Automotive & Construction & Electrical & Electronics & IT/Telecom & Mechanical & Missing \\
\hline Percentage of respondents & 28.5 & 3 & 10.6 & 8.6 & 17.2 & 12.6 & 16.6 & 2.9 \\
\hline Average age & 26 years & 20 years & 25 years & 22.5 years & 23 years & 17.5 years & 24 years & 37.5 years \\
\hline $\begin{array}{l}\text { Median number of } \\
\text { employees }\end{array}$ & 130 & 175 & 40 & 105 & 150 & 72 & 61 & N/A \\
\hline $\begin{array}{l}\text { Average revenue (million } \\
\text { \$US) }\end{array}$ & 24.5 & 80 & 13 & 24.5 & 31 & 21.5 & 13 & 14 \\
\hline
\end{tabular}


TABLE 2: Descriptive and Correlation Matrix of Latent Variables*

\begin{tabular}{|c|c|c|c|c|c|c|c|c|c|c|c|}
\hline & Mean & S.D. & TMC & SSP & SSC & CFC & TECH & REW & TRA & CT & RPS \\
\hline TMC & 4.69 & 1.27 & 0.894 & & & & & & & & \\
\hline SSP & 2.75 & 1.38 & 0.379 & N/A & & & & & & & \\
\hline SSC & 1.12 & 0.87 & 0.266 & $0.614^{5}$ & N/A & & & & & & \\
\hline CFC & 4.66 & 1.22 & 0.311 & 0.234 & 0.146 & 0.818 & & & & & \\
\hline TECH & 5.10 & 1.38 & 0.349 & 0.429 & 0.348 & 0.393 & 0.920 & & & & \\
\hline REW & 4.32 & 1.15 & 0.344 & 0.349 & 0.336 & 0.373 & 0.403 & 0.865 & & & \\
\hline TRA & 4.27 & 1.62 & 0.241 & 0.224 & 0.237 & 0.312 & 0.524 & 0.357 & 0.916 & & \\
\hline CT & 5.17 & 0.98 & 0.197 & 0.296 & 0.212 & 0.413 & 0.493 & 0.525 & 0.435 & 0.846 & \\
\hline RPS & 3.99 & 1.55 & 0.325 & 0.208 & 0.234 & 0.211 & 0.225 & 0.261 & 0.137 & 0.135 & 0.930 \\
\hline SV & 3.11 & 2.38 & 0.252 & 0.301 & 0.133 & 0.050 & 0.242 & 0.173 & 0.049 & 0.247 & -0.012 \\
\hline
\end{tabular}

*Notes: Square root of average variance extracted appear on the diagonal. TMC: top management commitment and visionary leadership ; SSP: SSP business orientation; SSC: SSC business orientation; CFC: cross-functional communication of service employees; TECH: service technology; REW: service rewards; TRA: service training; CT: customer treatment; RPS: relative product sales; SV: service volume.

\footnotetext{
${ }^{5}$ If we model SSP and SSC as reflective constructs (even though the loading for proactiveness was slightly below 0.5), we note that the square root of the AVE (respectively 0.658 and 0.648 ) is above the correlation between the constructs (0.614). Therefore, we can empirically conclude that SSP and SSC are distinct constructs. Results displaying discriminant validity may be stronger; however they should also be interpreted in light with the theoretical justifications for conceptualizing SSP and SSC as distinctive constructs. We also note that cross-loadings are not substantial in magnitude.
} 
TABLE 3: Research Findings

\begin{tabular}{|c|c|c|c|c|c|c|}
\hline \multirow{2}{*}{$\begin{array}{l}\text { Alternative Models } \\
\text { Service Orientations }\end{array}$} & \multicolumn{2}{|c|}{ MODEL 1} & \multicolumn{2}{|c|}{ MODEL 2} & \multicolumn{2}{|c|}{ MODEL 3} \\
\hline & $\begin{array}{c}\text { SSP Bus. } \\
\text { Orientation }\end{array}$ & $\begin{array}{c}\text { SSC Bus. } \\
\text { Orientation }\end{array}$ & SSP Bus. Orientation & SSC Bus. Orientation & SSP Bus. Orientation & $\begin{array}{l}\text { SSC Bus. } \\
\text { Orientation }\end{array}$ \\
\hline TMC $(H 3 a 1 \& 2)$ & $0.226 * *$ & 0.127 & $0.227 * *$ & 0.128 & $0.227 * *$ & 0.128 \\
\hline REW (H4a $1 \& 2)$ & $0.156 * *$ & $0.220 * *$ & $0.158 * *$ & $0.222 * *$ & $0.158 * *$ & $0.222 * *$ \\
\hline TECH $(H 5 a$ l\&2) & $0.287 * *$ & $0.240 * *$ & $0.290 * *$ & $0.242 * *$ & $0.290 * *$ & $0.242 * *$ \\
\hline $\mathrm{CFC}(\mathrm{H} 6$ a $1 \& 2)$ & -0.001 & -0.065 & -0.009 & -0.07 & -0.009 & -0.07 \\
\hline$R$-square & 0.264 & 0.182 & 0.263 & 0.182 & 0.263 & 0.183 \\
\hline Outcome Variables & $\begin{array}{c}\text { Relative Product } \\
\text { Sales }\end{array}$ & Service Volume & $\begin{array}{c}\text { Relative Product } \\
\text { Sales }\end{array}$ & Service Volume & $\begin{array}{c}\text { Relative Product } \\
\text { Sales }\end{array}$ & Service Volume \\
\hline \multicolumn{7}{|l|}{ Covariates } \\
\hline Age & 0.023 & 0.007 & 0.03 & -0.008 & 0.041 & -0.026 \\
\hline Delivery Mode & 0.019 & -0.102 & -0.092 & 0.032 & -0.064 & 0.027 \\
\hline $\begin{array}{r}\text { Direct effects } \\
\text { SSC Oriented }(H 1 a \& 2 a)\end{array}$ & $0.176 * *$ & -0.084 & $0.146 * *$ & -0.104 & $0.173 * *$ & -0.09 \\
\hline SSP Oriented $(H 1 b \& 2 b)$ & 0.091 & $0.351 * *$ & 0.03 & $0.289 * *$ & -0.029 & $0.288 * *$ \\
\hline \multicolumn{7}{|l|}{ Moderators } \\
\hline TMC & & & $0.255^{* *}$ & 0.142 & $0.255^{* *}$ & $0.157 *$ \\
\hline REW & & & --- & 0.037 & --- & -0.019 \\
\hline TECH & & & --- & 0.116 & --- & 0.130 \\
\hline $\mathrm{CFC}$ & & & 0.131 & --- & 0.131 & --- \\
\hline TRA & & & & & --- & -0.159 \\
\hline \multirow{2}{*}{\multicolumn{7}{|c|}{$\begin{array}{r}\mathrm{CT} \\
\text { Interaction effects }\end{array}$}} \\
\hline & & & & & & \\
\hline $\mathrm{TMC} \times \operatorname{SSC}(H 3 b)$ & & & -0.052 & -0.017 & -0.052 & -0.009 \\
\hline REW x SSP $(H 4 b 1)$ & & & --- & -0.127 & --- & -0.027 \\
\hline REW x SSC (H4b2) & & & --- & -0.028 & --- & -0.105 \\
\hline TECH x SSP $(H 5 b 1)$ & & & --- & $0.165 * *$ & --- & $0.329 * *$ \\
\hline TECH x SSC (H5b2) & & & --- & -0.107 & --- & $-0.225^{*}$ \\
\hline $\mathrm{CFC} \times \mathrm{SSC}(H 6 b)$ & & & $0.154 * *$ & --- & $0.154 * *$ & --- \\
\hline TRA $x \operatorname{SSP}(H 71)$ & & & & & --- & -0.157 \\
\hline TRA x SSC (H72) & & & & & --- & $0.229 * *$ \\
\hline CT x SSP $(H 81)$ & & & & & & -0.08 \\
\hline $\mathrm{CT} \times \mathrm{SSC}(H 82)$ & & & & & & -0.03 \\
\hline$R$-square & 0.076 & 0.095 & 0.171 & 0.152 & 0.171 & 0.212 \\
\hline Goodness of Fit & \multicolumn{2}{|c|}{0.330} & \multicolumn{2}{|c|}{0.352} & \multicolumn{2}{|c|}{0.399} \\
\hline
\end{tabular}


TABLE 4: Summary of Key Findings

SSP Business Orientation $=0.227 \mathrm{TMC}+0.158 \mathrm{REW}+0.290 \mathrm{TECH}$

SSC Business Orientation $=0.222 \mathrm{REW}+0.242 \mathrm{TECH}$

\section{Key findings (1)}

Top management's commitment to and visionary leadership of services does not have a significant effect on SSC business orientations; it does on SSP business orientations;

Service rewards and service technology are important drivers to both service business orientations;

In contrast to previous findings, cross-functional communication between service employees and the rest of the firm does not have a significant direct effect on service business orientations.

Relative Product Sales $=0.173 \mathrm{SSC}+0.255 \mathrm{TMC}+0.154 \mathrm{SSC}$ x CFC

\section{Additional Key findings (2)}

Relative product sales is a function of SSC only; there is no significant influence of SSP; The relationship between the SSC business orientation and relative product sales becomes stronger with increasing levels of cross-functional communication between service employees and the rest of the firm. Overall, we provide a nuanced view of the effects of the crossfunctional communication of service employees in manufacturing organizations.

Service volume $=0.288 \mathrm{SSP}+0.157 \mathrm{TMC}+0.217 \mathrm{CT}+0.329 \mathrm{SSP} \times \mathrm{TECH}-0.225 \mathrm{SSC} \mathrm{x}$ $\mathrm{TECH}+0.229$ SSC $\mathrm{x}$ TRA

\section{Additional Key findings (3)}

Service volume is a function of SSP only; there is no direct significant influence of SSC;

Top management's commitment to and visionary leadership of services has a direct influence on the creation of service volume;

Customer treatment has a direct influence on the creation of service volume (This confirms findings by Lytle, Hom and Mokwa (1998) rather than our hypothesis about customer treatment being a pure moderator);

The relationship between the SSP business orientation and service volume becomes stronger with increasing levels of service technology;

The relationship between the SSC business orientation and service volume becomes weaker with increasing levels of service technology;

The relationship between the SSC business orientation and service volume becomes stronger with increasing levels of service training. It is the only case when an SSC business orientation is positively associated to service volume. 


\section{APPENDIX}

APPENDIX A. Building the Research Framework based on Service Climate Literature \& Selected Quotes

\begin{tabular}{|c|c|c|c|c|c|}
\hline Author(s) & Journal & $\begin{array}{c}\text { Publication } \\
\text { Date }\end{array}$ & $\begin{array}{c}\text { Organizational Service Parameters } \\
\text { Defining Service Climate }\end{array}$ & $\begin{array}{l}\text { Support } \\
\text { during In- } \\
\text { Depth } \\
\text { Interviews } \\
\end{array}$ & GENERAL THEMES \\
\hline $\begin{array}{l}\text { Andrews and } \\
\text { Rogelberg }\end{array}$ & $\begin{array}{l}\text { Journal of } \\
\text { Business and } \\
\text { Psychology }\end{array}$ & 2001 & $\begin{array}{l}\text { Boss' service commitment } \\
\text { Service rewards and recognitions } \\
\text { Service communication between boss } \\
\text { and employee } \\
\text { Service leadership } \\
\text { Customer-perceived service quality }\end{array}$ & $\begin{array}{l}\text { No } \\
\text { Yes } \\
\text { No } \\
\text { Yes } \\
\text { Outcome }\end{array}$ & $\begin{array}{l}\text { Service rewards } \\
\text { Top management leadership }\end{array}$ \\
\hline $\begin{array}{l}\text { Dietz, Pugh, } \\
\text { and Wiley }\end{array}$ & $\begin{array}{l}\text { Academy of } \\
\text { Management } \\
\text { Journal }\end{array}$ & 2004 & $\begin{array}{l}\text { Employee's perspective on } \\
\text { organization's service orientation } \\
\text { Frequency of customer contact }\end{array}$ & $\begin{array}{l}\text { Yes } \\
\text { No }\end{array}$ & $\begin{array}{l}\text { (Too vague: Regroups all } \\
\text { dimensions) }\end{array}$ \\
\hline Johnson & $\begin{array}{l}\text { Personnel } \\
\text { Psychology }\end{array}$ & 1996 & $\begin{array}{l}\text { Service strategy } \\
\text { Service support/technology } \\
\text { Service systems } \\
\text { Information seeking } \\
\text { Service training } \\
\text { Reward and recognition } \\
\text { Sales and service relationship } \\
\text { Estimate of customer satisfaction }\end{array}$ & $\begin{array}{l}\text { Yes } \\
\text { Yes } \\
\text { Yes } \\
\text { Partially } \\
\text { Yes } \\
\text { Yes } \\
\text { Partially } \\
\text { Outcome }\end{array}$ & $\begin{array}{l}\text { Service strategy } \\
\text { Service technology } \\
\text { Service technology } \\
\text { Cross-functional communication } \\
\text { Service training } \\
\text { Service rewards } \\
\text { Cross-functional communication }\end{array}$ \\
\hline
\end{tabular}




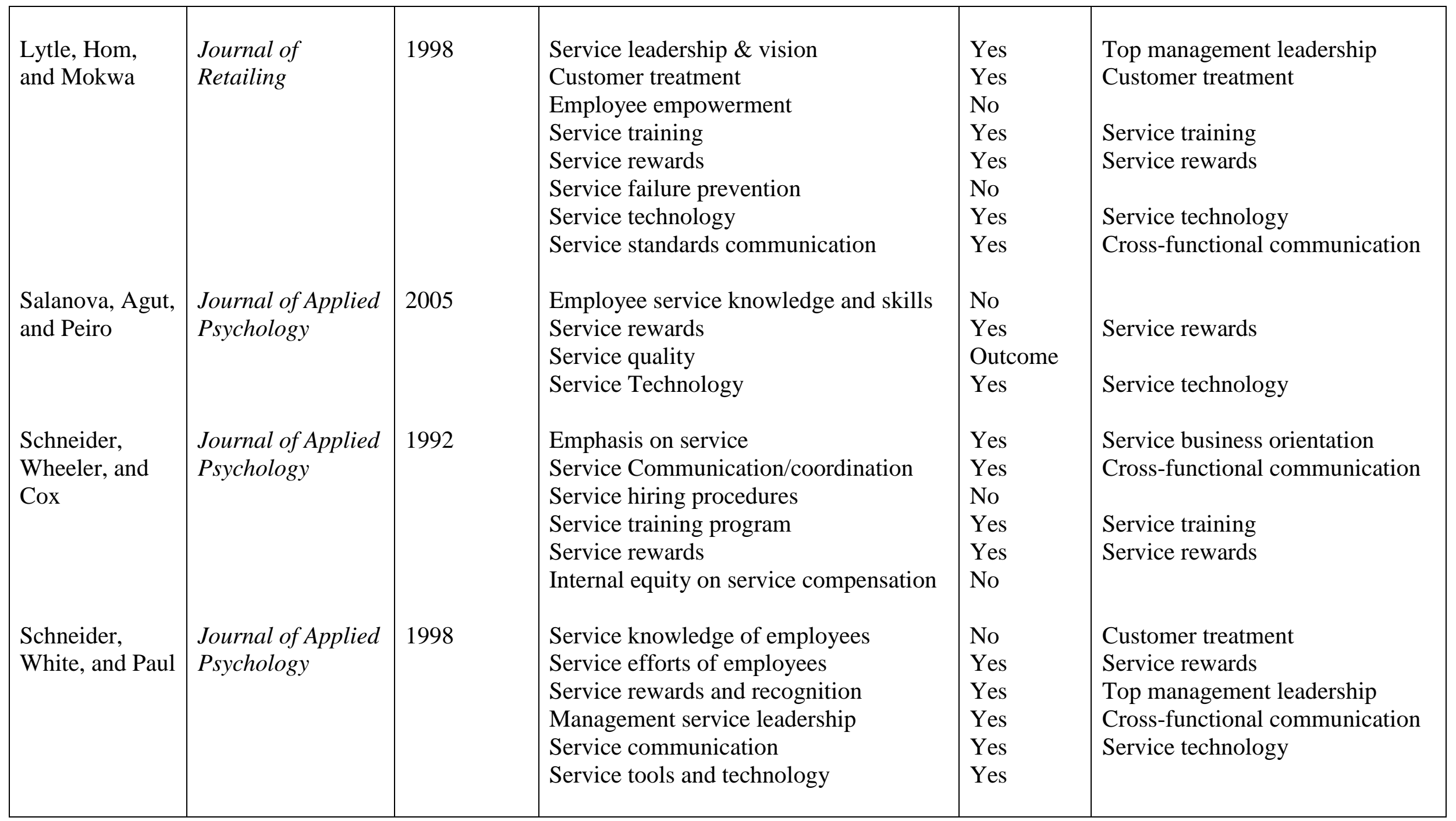




\section{Selected Quotes from the In-Depth Interviews}

\section{Original Framework}

Service leadership \& vision

Customer treatment

Service training

Service rewards

Service technology

Cross-functional communication of service employees

\section{Quotes}

"We [top management] are really changing this firm around. We want employees and our customer to see us as a service firm now. We need to constantly work on communicating service values" (service director, medical equipment manufacturing).

"When you deliver a service you need people with soft skills.... Most of our engineers would not know how to deal with clients. Actually, we tried to put engineers behind our help desk but it simply didn't work. They didn't feel valued for that work and, on top of that, customers were not really getting the right attention." (services manager, IT manufacturing) "If you want people to start acting differently, you have to explain to them what you want. Training is crucial because employees learn how to deal with different situations and profit from them. Once the customer is one the phone, you have one chance to make it right!" (services manager, IT manufacturing) "People also need to feel that their efforts will be rewarded, especially contact employees, because they deal with all the customers' problems, basically. They [contact employees] are the first people in the escalation procedure if our products go wrong and they need to do their job well." (services director, medical equipment manufacturing)

"We have customer databases that are helpful to estimate future service demands and product purchase of course." (services director, electronics manufacturing)

"The technology is important, especially for remote services. Customers really value that because it is time saving ... and we like it as well!" (services director, medical equipment manufacturing)

"I think engineers are starting to value our opinion.... They see that we know those products as well as they do. We also work on those products.... More and more, we can participate in meetings about new products and don't just send out information about product defect rates or mean time to repair for example." (services director, electronics manufacturing) 
APPENDIX B: List of Services Supporting Products (SSP) (12) and Services Supporting Clients (SSC) (8).

\begin{tabular}{lc}
\hline \multicolumn{1}{c}{ SSP } & SSC \\
\hline Product documentation & Financing services \\
Product transportation/delivery & Management of spare parts \\
Product installation & Process-oriented training (quality-driven \\
Help desk/call centre & including technology) \\
Product inspection/diagnosis & Business-oriented training (financially \\
Product repair/spare parts & driven/management training) \\
Product upgrades & Process-oriented consulting (quality-driven \\
Product refurbishing & including technology) \\
Product recycling/machine brokering & Business-oriented consulting (financially \\
Preventive maintenance & driven/management consulting) \\
Condition monitoring & Managing the maintenance function \\
Process-oriented engineering (testing, & Fully managing product-related operations \\
optimizing and simulating) & (complete outsourcing and ownership of \\
& product by vendor) \\
\hline
\end{tabular}

\section{APPENDIX C: Scales of Measurement Items}

\begin{tabular}{|c|c|}
\hline Scales & Measurement Items (primary industry segment) \\
\hline $\begin{array}{l}\text { Top } \\
\text { management's } \\
\text { commitment to } \\
\text { and visionary } \\
\text { leadership of } \\
\text { services } \\
\text { (Sureshchandar } \\
\text { Rajendran, and } \\
\text { Anantharaman } \\
\text { 2001) }\end{array}$ & $\begin{array}{l}\text { Is inclined to allocate resources and time for service management efforts } \\
\text { Is dynamic when it comes down to considering service management } \\
\text { Evaluates the effectiveness of its personal leadership regarding service } \\
\text { management }\end{array}$ \\
\hline $\begin{array}{l}\text { Service rewards } \\
\text { (Lytle, Hom, and } \\
\text { Mokwa 1998) }\end{array}$ & $\begin{array}{l}\text { Management provides incentives and rewards at all levels for service } \\
\text { quality, not just productivity } \\
\text { We noticeably celebrate excellent service through service reward systems }\end{array}$ \\
\hline $\begin{array}{l}\text { Cross- } \\
\text { functional } \\
\text { communication } \\
\text { of service } \\
\text { employees } \\
\text { (Li 1999) }\end{array}$ & $\begin{array}{l}\text { To what extent does the (customer) service department and the other } \\
\text { departments: } \\
\text { Communicate for new product development } \\
\text { Share information on customers } \\
\text { Share information about competitors' products and strategies } \\
\text { Cooperate in establishing new product development goals and priorities } \\
\text { Cooperate in generating and screening new product ideas and testing } \\
\text { concepts }\end{array}$ \\
\hline
\end{tabular}




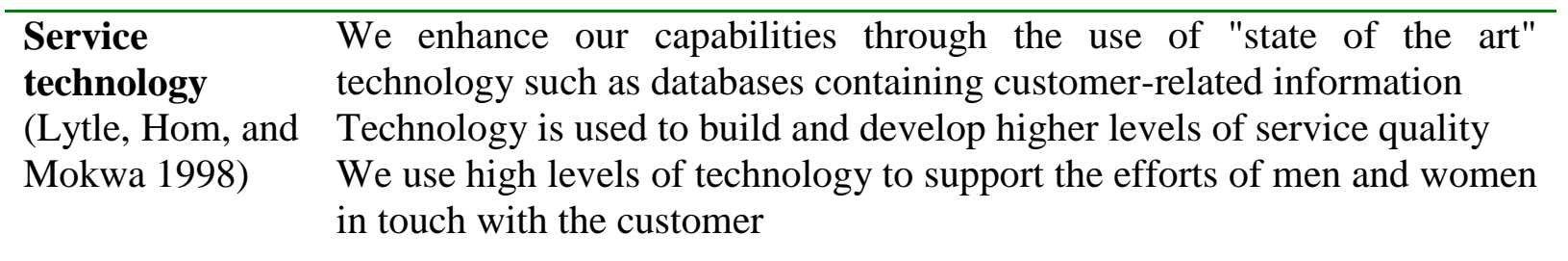

Service

business

orientation

(Homburg,

Hoyer, and

Fassnacht 2002)

Service training (Lytle, Hom, and Mokwa 1998)
Do you offer the following services [list of services presented in Table B] If the answer is "yes"; then:

- How many customers do you offer this service to? $(1=$ very few customers to 7 = very many customers)

- How proactive are you in offering the service to your customers (1 $=$ very passive; $7=$ very proactive)

Employees receive business/soft skills training that enhance their ability to deliver quality service

You spend time and effort in simulated training activities that help provide higher levels of service when actually encountering the customer

During training sessions, employees work through exercises to identify and improve attitudes towards customers.

Employees involved in customer service activities care for customers, as they would like to be cared for

Employees involved in customer service activities go the "extra mile" for customers

Employees involved in customer service activities go out of their way to reduce inconvenience for customers

Relative
Product Sales

(Hultink and Atuahene-Gima, 2000)

Relatively to your competitors, how has your company (business unit) performed over the last three business years in your primary industry segment in:

Gaining significant market share for new products

Generating high level of sales volume for new products

Quickly generating sales for new products

Exceeding sales targets set for new products

Assisting sales manager in achieving the objectives for new products

Service volume What percentage of your company's (business unit) revenues is generated by services: less than $10 \%$, more than 10 but less than 20, etc., more than $80 \%$ (8 categories).

Notes: Three items dropped after measurement purification are not included in this table. 
APPENDIX D:Loadings, Composite Reliability, and Average Variance Extracted (AVE)

\begin{tabular}{|c|c|c|c|c|c|}
\hline Construct & Items & Type & $\begin{array}{l}\text { Standard } \\
\text { Loadings/Weights }^{6}\end{array}$ & $\begin{array}{l}\text { Composite } \\
\text { Reliability }\end{array}$ & AVE \\
\hline $\begin{array}{l}\text { TMC to and } \\
\text { visionary } \\
\text { leadership of } \\
\text { services }\end{array}$ & $\begin{array}{l}1 \\
2 \\
3\end{array}$ & Reflective & $\begin{array}{l}0.89 \\
0.93 \\
0.86\end{array}$ & 0.923 & 0.799 \\
\hline Service rewards & $\begin{array}{l}1 \\
2\end{array}$ & Reflective & $\begin{array}{l}0.93 \\
0.92\end{array}$ & 0.928 & 0.865 \\
\hline $\begin{array}{l}\text { Cross-functional } \\
\text { communication } \\
\text { of service } \\
\text { employees }\end{array}$ & $\begin{array}{l}1 \\
2 \\
3 \\
4 \\
5\end{array}$ & Reflective & $\begin{array}{l}0.76 \\
0.80 \\
0.81 \\
0.85 \\
0.86\end{array}$ & 0.910 & 0.669 \\
\hline $\begin{array}{l}\text { Service } \\
\text { technology }\end{array}$ & $\begin{array}{l}1 \\
2 \\
3\end{array}$ & Reflective & $\begin{array}{l}0.91 \\
0.94 \\
0.91\end{array}$ & 0.943 & 0.846 \\
\hline $\begin{array}{l}\text { SSP business } \\
\text { Orientation }\end{array}$ & $\begin{array}{l}\text { \# Of service off } \\
\text { Emphasis on } \\
\text { service } \\
\text { Proactiveness }\end{array}$ & Formative & $\begin{array}{l}0.67(0.77) \\
0.25(0.41) \\
0.73(0.74)\end{array}$ & N.A. & N.A. \\
\hline $\begin{array}{l}\text { SSC business } \\
\text { Orientation }\end{array}$ & $\begin{array}{l}\text { \# Of service off } \\
\text { Emphasis on } \\
\text { service } \\
\text { Proactiveness }\end{array}$ & Formative & $\begin{array}{l}0.78(0.89) \\
0.25(0.42) \\
\\
0.60(0.61)\end{array}$ & N.A. & N.A. \\
\hline Service training & $\begin{array}{l}1 \\
2 \\
3\end{array}$ & Reflective & $\begin{array}{l}0.96 \\
0.91 \\
0.87\end{array}$ & 0.940 & 0.840 \\
\hline $\begin{array}{l}\text { Customer } \\
\text { treatment }\end{array}$ & $\begin{array}{l}1 \\
2 \\
3\end{array}$ & Reflective & $\begin{array}{l}0.79 \\
0.82 \\
0.92\end{array}$ & 0.882 & 0.715 \\
\hline $\begin{array}{l}\text { Relative product } \\
\text { Sales }\end{array}$ & $\begin{array}{l}1 \\
2 \\
3 \\
4 \\
5\end{array}$ & Reflective & $\begin{array}{l}0.84 \\
0.88 \\
0.87 \\
0.91 \\
0.81\end{array}$ & 0.937 & 0.748 \\
\hline Service volume & 1 & N.A. & N.A. & N.A & N.A. \\
\hline
\end{tabular}

\footnotetext{
${ }^{6}$ Weights are reported for formative indicators. Loadings to establish discrimant validity between the formative indicators (if modelled as reflective) are indicated in brackets.
} 